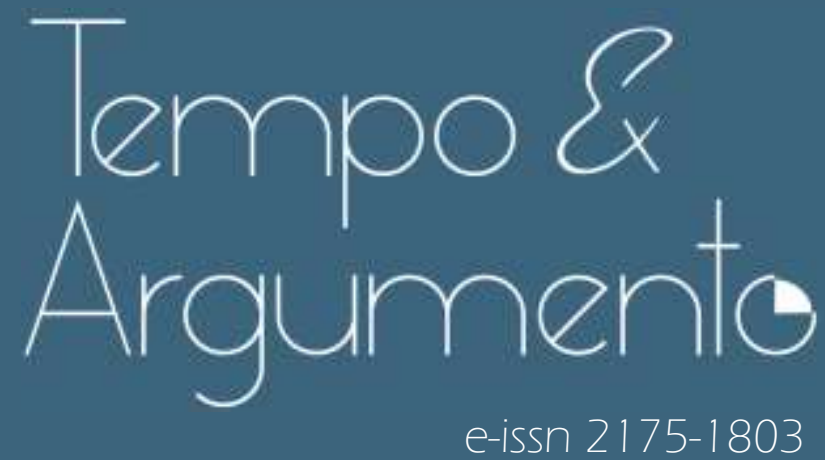

La revista Militancia Peronista para la Liberación (1973-1974) y su "Sección Polémica": una representación del intercambio epistolar entre obreros de base

anariela Stavale

Doctora en Ciencias Sociales, Facultad de Humanidades y Ciencias de la

Educación de la Universidad Nacional de la Plata / CONICET.

La Plata - ARGENTINA

memoria.fahce.unlp.edu.ar/perfiles/1315StavaleM

mari_stavale@yahoo.com.ar

(1) orcid.org/0000-0002-2660-6591

Para citar este articulo (ABNT):

STAVALE, Mariela. La revista Militancia Peronista para la Liberación (1973-1974) y su "Sección Polémica": una representación del intercambio epistolar entre obreros de base. Tempo e Argumento, Florianópolis, v. 13, n. 34, e0305, set./dez. 2021.

do http://dx.doi.org/10.5965/2175180313342021e0305

Recebido: 21/07/2020

Aprovado: 14/08/2021 


\title{
La revista Militancia Peronista para la Liberación (1973-1974) y su "Sección Polémica": una representación del intercambio epistolar entre obreros de base
}

\begin{abstract}
Resumen
Este artículo analiza una revista de la nueva izquierda argentina: Militancia Peronista para la Liberación (1973-74). La publicación es expresiva de una corriente específica dentro del peronismo revolucionario: "el alternativismo" que, a comparación con otros actores, ha sido poco estudiada. También, expresa el proceso de transformación identitaria para el grupo político que surgió en torno a la publicación, visibilizando una vía de radicalización política particular: la "izquierdización" del peronismo. Aquí nos concentramos en el análisis de la Sección Polémica, que representa un intercambio epistolar entre personajes obreros y peronistas. A diferencia del resto de las notas periódicas de la revista, Sección Polémica supuso un "contrato de lectura" específico, con lógicas propias y la construcción de múltiples lectores. Como veremos, la sección es un prisma a partir del cual es posible mostrar aquel proceso de transformación identitaria y los sentidos de un peronismo en disputa, reconstruyendo las apuestas del grupo político y los debates con los sectores internos del movimiento peronista, Perón y, también, con las organizaciones movimientistas del peronismo revolucionario.
\end{abstract}

Palabras clave: identidad política; sección polémica; Perón; alternativismo; movimientismo.

\section{The Peronist Militancy for Liberation magazine (1973-1974) and its "Controversial Section": a representation of the epistolary exchange between grassroots workers}

\begin{abstract}
This article analyzes a magazine of the new Argentine left: Peronist Militancy for Liberation (1973-74). The publication is expressive of a specific current within revolutionary Peronism: "alternativeism" that, compared to other actors, has been little studied. It also expresses the process of identity transformation for the political group that emerged around the publication, making visible a particular path of political radicalization: the "leftization" of Peronism. Here we concentrate on the analysis of the Controversial Section, which represents an epistolary exchange between worker and Peronist characters. Unlike the rest of the periodical notes of the magazine, the Controversy Section represented a specific "reading contract", with its own logic and the construction of multiple readers. As we will see, the section is a prism from which it is possible to show that process of identity transformation and the meanings of a disputed Peronism, reconstructing the stakes of the political group and the debates with the internal sectors of the Peronist movement, Perón and, also, with the movement organizations of revolutionary Peronism.
\end{abstract}

Keywords: political identity; controversial section; Perón; alternativism; movementism. 


\section{Introducción.}

El presente artículo se concentra en la revista Militancia Peronista para la Liberación (MPL): una publicación que, dirigida por Rodolfo Ortega Peña y Eduardo Luis Duhalde, circuló en Argentina durante los convulsionados años setenta y fue expresión de la corriente alternativista, dentro del peronismo revolucionario. Este trabajo forma parte de una investigación más amplia, que reconstruye y analiza aquella vertiente -poco explorada a comparación de otros sectores del peronismo revolucionario- con el objetivo de seguir aportando al conocimiento sobre la nueva izquierda argentina; categoría que nombra a ese "movimiento de movimientos", profundamente heterogéneo, protagonista del ciclo de movilización y radicalización política, durante las décadas del sesenta y setenta (TORTTI, 2009, 2014).

Asumir la perspectiva de la nueva izquierda, resulta potente pues habilita una mirada de conjunto, que no circunscribe el proceso de movilización social y radicalización política al análisis de la violencia armada. Perder de vista la complejidad de la trama en la que se inscribieron los actores que la compusieron, trae el riesgo de obturar la comprensión de un período complejo, cargado de tensiones y expectativas que, además, concitó adhesiones en importantes sectores de la sociedad. En efecto, aquí abordamos la experiencia de un grupo político ${ }^{1}$ que giró en torno a una revista y se mantuvo independiente de las organizaciones armadas actuantes al momento de su publicación (STAVALE, 2018).

Pero, además, la nueva izquierda se entiende como el emergente de la convergencia de tradiciones político-culturales diferentes, marco en la cual, desde los tempranos sesenta (e iluminados por el faro revolucionario que llegaba de Cuba y por los movimientos liberacionistas del tercer mundo) se re-definieron las identidades políticas existentes y surgieron otras nuevas. En resumen, como hemos apuntado con González Canosa en un trabajo reciente, se trata de un enfoque que no circunscribe el fenómeno a las experiencias armadas ni tampoco,

\footnotetext{
"En nuestra tesis doctoral, desarrollamos la noción de "grupo político" pues a pesar de que el equipo editorial de MPL fue extremadamente pequeño, la experiencia político-editorial incluyó a todos aquellos que se acercaron al espacio de sociabilidad de la revista, identificado con las posiciones políticas que allí se generaron (STAVALE, 2018)
} 
lo reduce a los itinerarios de la izquierda, sino que incluye otras hibridaciones, como las que surgieron en torno al peronismo (2021).

Desde estas lentes analíticas, lo primero que debemos decir es que, difícilmente, podamos analizar MPL sin realizar un análisis que sea, a la vez, diacrónico y sincrónico. Diacrónico, pues las posiciones de la revista se asentaron sobre la experiencia del grupo político que giró en torno a ella; sus miembros venían participando del movimiento político y cultural de los años sesenta, realizando una apropiación selectiva de la tradición peronista re-significada a la luz de los aportes de un "marxismo nacional" y de un enfoque revisionista de la historia (SIGAL, 2002)². Sincrónico pues, a través de ella, es posible analizar la complejidad de los primeros meses del tercer gobierno peronista: MPL se publicó por primera vez el 14 de junio de 1973 -nutrida por las ilusiones revolucionarias que generaba el triunfo peronista de Cámpora- y fue clausurada el 30 de marzo de 1974, por el gobierno de Perón. Sus fechas extremas condensan simbólicamente el auge y la descomposición de las expectativas revolucionarias que importantes sectores sociales habían depositado en el regreso peronista al gobierno y al poder ${ }^{3}$.

Este artículo analiza una sección específica de MPL: la Sección Polémica, que representó un intercambio epistolar entre obreros-militantes “de base”. En términos generales, el análisis de esta sección busca dar cuentas de un proceso más amplio: la izquierdización de la identidad peronista del grupo MPL, a partir de la acentuación temprana del clasismo y la asunción de unperonismo marxista. ${ }^{4}$ Debemos decir que aquí, entendemos que las identidades no

\footnotetext{
${ }^{2}$ Debemos decir que, sin embargo, la dimensión diacrónica no puede hacernos perder de vista que los historiadores debemos empatizar con los dilemas que enfrentan los actores colocándonos en ese punto de la trama en el que, para ellos, "todo está por hacerse" (PASTORIZA, 2011, p. 245). ${ }^{3}$ En 1955, el segundo gobierno de J.D. Perón fue derrocado por un golpe militar que expresó la alianza de un sector de las fuerzas armadas y actores políticos diversos como el radicalismo o los partidos de la izquierda tradicional. El golpe, auto denominado "revolución libertadora", abrió un período atravesado por un proceso de radicalización social y política creciente, la deslegitimación del Estado y una inestabilidad político-económica crónica que, en una situación de "empate hegemónico", siguió girando en torno a "la cuestión del peronismo" (PORTANTIERO, 1977)

${ }^{4}$ Nos estamos refiriendo a un "cauce de radicalización política" particular, que distingue a este grupo político (y en general, a los actores del alternativismo) de otros actores del peronismo revolucionario: la izquierdización de la identidad peronista de actores que, en gran medida, provenían de las entrañas del movimiento. La idea de "cauces de radicalización política" es acuñada por González Canosa para pensar un itinerario inverso: el de las Fuerzas Armadas Revolucionarias (FAR), organización que, proveniente del marxismo, se "peronizó" a principios de los $70^{\prime}(2021)$.
} 
permanecen fijas; son relacionales y deben definirse como un proceso cambiante e inestable de relaciones de identificación, que mutan al calor de la invención de una tradición y a partir del vínculo entablado con otras tradiciones, con otros actores y con prácticas pasadas y presentes (BARTH,1976; GIMENEZ,2007). En términos particulares, analizaremos las especificidades de una sección que, a diferencia del resto de las notas periódicas de la revista, supuso un "contrato de lectura” propio y la construcción de múltiples lectores. Es decir, indagaremos sobre una serie de cartas ficticias que simularon una relación epistolar entre trabajadores peronistas y que tuvieron como destinatarios implícitos a sectores del peronismo, con quienes el grupo MPL estaba disputando los sentidos de su identidad política -como los dirigentes políticos y gremiales del movimiento, el propio Perón o las organizaciones hegemónicas del peronismo revolucionario.

Entonces, nos centraremos en el análisis de la sección como medio para dar cuenta de la trayectoria de radicalización del grupo político que publicó MPL, sus apuestas y la forma en que estas mutaciones, marcaron el ritmo de los debates que la revista "buscó instalar" entre los trabajadores peronistas. Con estos objetivos, la primera sección reconstruye su contexto general, los debates que animaron al peronismo revolucionario y la conformación del grupo político en torno a la publicación de MPL. Luego, caracterizaremos la estructura formal de la revista y de la Sección Polémica que, como veremos, supuso un "contrato de lectura" particular. Finalmente, repasamos las "cartas de la polémica” para reponer y analizar ese proceso de transformación identitaria, a partir de un conjunto de ejes que abonan a mostrar la radicalización política del grupo. Nos referimos a 1| la experiencia del tercer gobierno peronista 2| el liderazgo de Perón 3| el debate con otros sectores del peronismo revolucionario, específicamente: Montoneros y Juventud Peronista (JP).

\section{(La) Militancia y su contexto.}

La decisión de publicar MPL se produjo como respuesta a un cambio de coyuntura: el triunfo electoral del peronismo que, en 1973, simbolizó el levantamiento de una proscripción que había durado 18 años y el fin de la 
dictadura militar que había llegado al gobierno, en 196655. La salida electoral con participación del peronismo, se produjo como consecuencia de un proceso complejo que inició en 1971, cuando la presidencia de facto del Gral. Lanusse, lanzo el "Gran Acuerdo Nacional”. Este plan político tuvo varios propósitos: entre ellos, restituir la legitimidad del Estado y frenar la confluencia entre lucha social y política que, tras el impulso que significó "el Cordobazo" en 19696, venía poniendo en jaque al sistema del orden, con el especial protagonismo de las organizaciones armadas peronistas y marxistas que, para principios de los años setenta, se encontraban en actividad.

En efecto, los actores de la izquierda peronista se nuclearon en torno a la "tendencia revolucionaria" (TRP) desde 1969. Entre ellos, podemos nombrar a organizaciones armadas como Fuerzas Armadas Peronistas (FAP) (DUHALDE; PEREZ, 2003; LUVECCE, 1993, RAIMUNDO, 2005, STAVALE, 2012), Montoneros (CAMPOS, 2016; GILLEPSIE, 2008; LANUSE, 2005; OTERO, 2017; SALCEDO, 2011; SLIPAK, 2015, entre otros) o Fuerzas Armadas Revolucionarias (FAR) (González Canosa, 2021), organizaciones más bien insurreccionalistas, como el Movimiento Revolucionario 17 de Octubre (MR17) (GURRUCHARRI et. al, 2020), los "frentes de masas", agrupamientos barriales, gremiales, estudiantiles, político-culturales y personalidades políticas, identificadas con el ala de izquierda del peronismo (GONZÁLEZ CANOSA; STAVALE, 2021).

Como es posible observar, la TRP fue un espacio heterogéneo (LENCI, 1999, STAVALE, 2018; TOCHO, 2020); sin embargo, a pesar de esta diversidad, ha sido reducida a Montoneros y JP, por ser sus organizaciones hegemónicas y por el crecimiento exponencial y sostenido de ambas. Pero lejos de poder homogeneizarse, aquel espacio político estuvo surcado por disputas en torno a una serie de tópicos político-ideológicos importantes, como: 1| la forma de

\footnotetext{
${ }^{5}$ La dictadura militar presidida por el Gral. Onganía llegó al poder en 1966 y consolidó la primera experiencia del Estado burocrático-autoritario en Argentina, con un plan de largo aliento que preveía una re-fundación de la economía, de la sociedad y de la política.

${ }^{6}$ En 1969 se produjeron los estallidos populares de masas, conocidos como Rosariazo-CordobazoRosariazo, que pueden considerarse como el acta de defunción de la dictadura. Sus consecuencias fueron contundentes: al calor del proceso, surgieron otras insurrecciones y puebladas a lo largo y ancho del país, direcciones gremiales clasistas y combativas en el movimiento obrero y las organizaciones armadas, peronistas y marxistas, protagonistas de los años 70' (BALVÉ, 1989; BRENNAN, 1996; LAUFER, 2017; POZZI; SCHNEIDER, 2000)
} 
concebir el proceso revolucionario; 2| el carácter del movimiento peronista, de sus sectores internos y el rol de Perón o 3| la posibilidad (o no) de participar de los espacios formales del movimiento, para impulsar el proceso de transformación social. Como apuntamos con González Canosa, las posiciones asumidas en torno a estos clivajes, han permitido recoger (y sistematizar analíticamente) aquellas corrientes en disputa: el "alternativismo" -vinculado al lanzamiento de la Alternativa Independiente (AI) por parte de las FAP, en $1971^{7}$ - y el "movimientismo" (2021)․ A la vez, Lanusse propone una categoría intermedia: el "tendencismo", para pensar aquellos actores que no pueden reducirse a ninguna de las posiciones polares (LANUSSE, 2005). Finalmente debemos decir que estas corrientes son "tipos ideales", es decir, construcciones conceptuales que no se dieron en estado puro, pero resultan operativas para analizar el posicionamiento de los actores.

En términos generales, la corriente alternativista supuso concepciones clasistas y profundamente antiburocráticas, que plantearon al "socialismo" como objetivo final del proceso revolucionario y a la clase obrera como su principal protagonista. Desde estas lentes, rechazaban la posibilidad de una alianza de clases con los sectores de la burguesía nacional y denunciaban contradicciones insalvables dentro del movimiento, concibiendo a las "burocracias sindical y política" como un enemigo clave. Finalmente, aunque no se explicitara, Perón no era considerado un líder revolucionario aunque sí popular, capaz de conducir, al menos, una parte del proceso: el de la liberación nacional (GONZÁLEZ CANOSA, 2015; STAVALE 2018). En el otro extremo, los sectores movimientistas afirmaban que la "liberación nacional" era el objetivo del proceso revolucionario. Bajo esta perspectiva, definían al "imperialismo y la oligarquía" como los principales enemigos, al movimiento peronista como revolucionario en su conjunto y a Perón, como su líder indiscutido (CULLEN, 2008). Finalmente, las posiciones “tendencistas" denunciaban contradicciones al interior del movimiento, pero no dejaban de concebirlo como potencialmente revolucionario. Respecto de Perón,

\footnotetext{
'La Alternativa Independiente proponía la construcción de una organización de base, constituida para y por la clase obrera e independiente de las estructuras formales del movimiento peronista. "Las nociones de "alternativismo" y "movimientismo" fueron también, categorías nativas: es decir, fueron utilizadas por los actores, para caracterizar el posicionamiento de unos y otros, en los debates al interior del peronismo revolucionario.
} 
La revista Militancia Peronista para la Liberación (1973-1974) y su "Sección Polémica": una representación del intercambio epistolar entre obreros de base

Mariela Stavale

apostaban por la posibilidad de que se "volcara" en sentido revolucionario, si la TRP lograba hegemonizar el movimiento (LANUSSE, 2005, p. 255-256)

Como adelantamos, MPL fue una expresión político-cultural de la corriente alternativista que, a la vez, estuvo formada por otros actores: las mencionadas FAP y el Peronismo de Base $(P B)^{9}$, Montoneros columna José Sabino Navarro (MCJSN)10 , el MR1711; gremios combativos como el de Farmacia (dirigido por Jorge Di Pascuale y Alfredo Ferraresi), el de obreros gráficos (encabezado por Raimundo Ongaro), Telefónicos (bajo el liderazgo de Julio Guillán) o personalidades políticas como la de Alicia Eguren, viuda de Cooke.

Los miembros del grupo MPL venían compartiendo espacios de experiencia previos, nucleados en torno a las figuras de Ortega Peña y Duhalde ${ }^{12}$. Todos ellos ${ }^{13}$ fueron intelectuales, abogados y militantes del movimiento

\footnotetext{
${ }^{9}$ Las FAP y el PB tuvieron orígenes diferentes, pero terminaron por confluir, tras un proceso de articulación que inició en 1971, luego del lanzamiento de la Al por parte de las FAP, las definiciones político-ideológicas que supuso y el cuestionamiento del “foquismo" inicial, que reorientó las prácticas políticas hacia "el basismo" como estrategia revolucionaria. Por su parte, los orígenes del PB son más difíciles de reconstruir. En términos generales, podemos decir que esta organización política surgió en Córdoba y paralelamente, en Tucumán, íntimamente conectada a las diferentes vertientes del sindicalismo clasista en 1970. Luego, fue replicándose en diferentes zonas del país, al calor de la coordinación de experiencias disímiles y del proceso de articulación con las FAP, que impulsó su surgimiento en aquellas zonas donde no se había desarrollado. Aunque, como reconstruye Lanusse (2005), existieron otros grupos que se autodenominaron "peronismo de base" desde 1968 -como la organización protomontonera, "Lealtad y Lucha"- lo cierto es que abandonaron esa denominación al conectarse a organizaciones como Montoneros e, incluso, FAR. A pesar de la complejidad referida, las investigaciones existentes sobre FAP y PB tendieron a concentrarse sólo en las FAP, haciendo énfasis en el período que va desde su surgimiento hasta el lanzamiento de la Al y sus consecuencias (DUHALDE; PEREZ, 2003; LUVECCE, 1993; RAIMUNDO, 2004; STAVALE, 2012).

${ }^{10}$ La columna Montoneros José Sabino Navarro surge en 1972, como una escisión de la organización Montoneros a partir de una identificación con el "alternativismo". Seminara reconstruye los itinerarios de esta fractura y la constitución de la nueva organización a partir de dos ejes de disidencia: las formas de concebir la lucha armada y de pensar el trabajo junto con el movimiento obrero (2015).

${ }^{11} E$ L MR17 surge como tal en 1970, bajo el liderazgo de Gustavo Rearte, pero sus orígenes se remontan a las experiencias del MRP y de la JRP, surgidas en las entrañas del movimiento peronista en 1964. En 1970, asumen la nueva nominación junto a un cambio de orientación, consistente en privilegiar la militancia de base y dejar en segundo plano la actividad militar. Por otra parte, el FRP dirigido por Armado Jaime, tuvo una importancia considerable en el norte argentino y desarrolló acciones armadas. En 1975, ambas organizaciones se fusionaron para crear el FR17 (Gurrucharri et. al. 2020).

${ }^{12}$ Ortega Peña y Duhalde comenzaron su militancia juntos, en las entrañas del movimiento peronista. Fueron abogados laboristas para la CGT e intelectuales del revisionismo histórico, durante los años sesenta (CELECIA; WAISBERG, 2005; ROT, 2017; STAVALE, 2018)

13 Destacamos a Vicente Zito Lema, Mario Hernández, Roberto Sinigalgia, Ignacio Velez, Carlos González Gartland, Ricardo Carpani, Diego Muñiz Barreto, Alicia Euguren, Mónica Peralta Ramos, Rubén Dri etc. La trayectoria de cada uno se vincula, más o menos, con la izquierda marxista. El grupo contaba con la colaboración de organizaciones como FAP, PB, Columna José Sabino
} 
peronista desde los tempranos sesenta e, ya en los setenta, muchos formaron parte de la "Gremial de Abogados", defendiendo presos políticos durante la dictadura (CHAMA, 2010) o de experiencias político-editoriales como la revista Nuevo Hombre en su primera época (STAVALE, 2018). La impronta de la identidad peronista del grupo dio cuentas de una relación fluida con el marxismo que, en términos generales, era "situado" en el lugar de la teoría: como herramienta para analizar la sociedad ${ }^{14}$. La identidad política se definía peronista y revolucionaria, se articulaba en torno a la experiencia de la clase obrera y entendía que "ningún verdadero marxista" podía ubicarse por fuera del movimiento de masas. El grupo reconocía entre sus maestros a Hernández Arregui o Puiggrós -personalidades claves en el vínculo entre marxismo y peronismo- y se reivindicaba heredero de J.W. Cooke quien, además, había sido el nexo político con la experiencia cubana.

Estas huellas tuvieron una particular influencia en la asunción de posiciones alternativistas y en el proceso de izquierdización de la identidad peronista del grupo durante la publicación de MPL. Es que la coyuntura del tercer gobierno peronista se volvió violentamente adversa para los sectores revolucionarios; como veremos, una particularidad de MPL fue la explicitación temprana del enfrentamiento con la gestión peronista y con el liderazgo de Perón, sin que ello implique abandonar al peronismo como identidad política.

Este proceso de transformación identitaria puede identificarse a partir de diferentes momentos que, delimitados por acontecimientos concretos, fueron marcando el ritmo de esa mutación: el momento de las expectativas revolucionarias -que coincide con el gobierno de Cámpora; un momento transicional que, tras la renuncia del presidente y el interinato de Raúl Lastiri, puso de manifiesto la crisis identitaria del grupo político y, finalmente, tras la asunción de Perón a su tercera presidencia, el enfrentamiento con el viejo líder y la experiencia de su gobierno. Acorde con estas transformaciones, MPL evidenció su apuesta política por el "peronismo de abajo", tejiendo vínculos estrechos con las organizaciones políticas y gremiales alternativistas. Este dato es relevante

Navarro. También existen testimonios que afirman que la organización guevarista ERP había ayudado a financiar la revista.

${ }^{14}$ González Canosa (2021) acuña el concepto de "marxismo situado" para pensar el proceso de peronización de una organización como las FAR, proveniente de la izquierda guevarista. 
porque, como veremos, los protagonistas de la Sección Polémica se presentaron como obreros y militantes de "base", explicitando aquella relación.

\section{La Sección Polémica: un contrato de lectura.}

MPL se compuso por 38 ejemplares semanales, fue adquiriendo forma a medida que se fue realizando y, más temprano que tarde, consiguió tener un perfil y público. La tirada en aumento, la venta en puestos callejeros y la rápida expansión hacia algunas provincias del interior del país, permiten tener una pauta de la influencia que lograron construir. Entre las revistas de la época, se destacó por un estilo ácido y duramente crítico, que no sólo enfrentó a la derecha (peronista y no peronista), las fuerzas de seguridad y las fuerzas armadas sino, también, a las organizaciones hegemónicas de la TRP cuando no coincidieron con ellas; a las políticas del gobierno que consideraron erradas y, finalmente, al propio Perón (STAVALE, 2018).

Esta característica definió el "contrato de lectura" propuesto por la publicación. Siguiendo a Verón, el "contrato" es el nexo construido por la revista entre ella y sus múltiples lectores. Es decir, el vínculo entre ambos que, además, define qué lugar ocupa el enunciador y qué lugar ocupa el destinatario (VERÓN, 2004). MPL estableció ese vínculo desde su primera editorial: apelando al "nosotros", se definió a sí misma como "parte del pueblo peronista" y a sus lectores, al afirmar como principales destinatarios a "los cuadros militantes del Movimiento" (Revista MPL N01, 14/06/1973 p. 3).

Estas definiciones marcaron el ritmo de una determinada "modalidad del decir", orientada a construir ese colectivo. MPL fue una revista escrita por intelectuales y militantes y esta característica se reflejó en la complejidad de las notas publicadas, el lenguaje utilizado, el tipo de análisis sobre la realidad política, la utilización del humor irónico, las críticas a las políticas del gobierno, etc. Uno de los objetivos del grupo MPL, fue incidir en el debate político al interior de la TRP. La revista no fue orgánica a ninguna de las organizaciones revolucionarias y, sin embargo, devino en un actor político más, que realizó apuestas que pretendieron ser hegemónicas. 
Pero, como hemos adelantado, la Sección Polémica tuvo su propia lógica editorial; de alguna forma, podríamos decir que se trató de un contrato de lectura particular dentro del general, propuesto por la revista. Esta sección también fue adquiriendo forma a medida que fue publicándose; la primera carta firmada por "Francisco" poco tiene que ver con las que vinieron después: su destinatario es impersonal (se encuentra dirigida a un "compañero") y, a diferencia del resto, su escritura es sofisticada. Sin embargo, ya en su segunda publicación, las cartas comenzaron a forjar otra "modalidad de decir", caracterizada por un lenguaje coloquial que simuló ser el de las bases y un estilo íntimo, propio de la conversación personal. A partir de esta estrategia, podríamos suponer que el grupo político buscó representar debates que podían llegar a darse -y/o que la publicación buscaba instalar - entre la clase obrera. Todos los personajes de la sección eran trabajadores y militantes peronistas.

El intercambio epistolar tuvo dos protagonistas centrales: "El Negro" y "Francisco", que firmaron todas las cartas. Sin embargo, el diálogo entre ambos fue sumando nuevos personajes pues, en sus escritos, aquellos reponían discusiones sostenidas con "compañeros peronistas" de militancia y trabajo, recreando una pluralidad de voces que lograba representar las heterogéneas posiciones políticas que, en tensión, estaban dinamizando las discusiones al interior de la TRP. Entre ellas, debemos mencionar la realidad del Movimiento, las decisiones políticas del gobierno, el rol de Perón o la actuación de las organizaciones del peronismo revolucionario. Así, apareció “Olegario”, quien tomó especial protagonismo, por sus posiciones izquierdistas que, en general, aparecen “marcando la línea” de las discusiones políticas (siempre tiene la última palabra y es un personaje "consultado" por los demás). Una característica interesante es que, junto al "Chango Boedo", representan a la militancia del interior del país: ambos discutían con "los porteños" que creían "saberlo todo". Estas características pueden vincularse a la militancia revisionista de los dirigentes del grupo político: MPL introducía una fisura característica de la sociedad argentina (las diferencias históricas entre el interior y Buenos Aires), cuestionando la histórica subsunción de las experiencias regionales, a la realidad política de la provincia capitalina. 
Otro rasgo definitorio para hablar de un particular "contrato de lectura" fueron los autores y lectores construidos en esta sección. Retomando a Eco, es posible distinguir entre las figuras de autor/lector "empírico" y “modelo”. El "autor empírico" es el sujeto de la enunciación textual quien, además, en el acto de decir, formula una hipótesis de "lector modelo". Por su parte, los lectores "empíricos" también deben fabricarse una hipótesis de "autor modelo" y, en esta tarea, las estrategias del texto y la circunstancia de la enunciación resultan claves (ECO, 1987, p. 8). A partir de la representación, el grupo MPL (autor empírico) construyó una herramienta para "decir lo indecible": tomó distancia del "autor modelo", diversificando voces y diferenciándose de ellas. De esta forma, no eran los integrantes del grupo político quienes formulaban las críticas al gobierno, Perón o las organizaciones hegemónicas de la TRP, sino -nada más y nada menos- que trabajadores peronistas.

Al mismo tiempo, la sección estableció a sus "lectores modelo": en primer lugar, el peronismo gobernante y, luego, el propio Perón. Un objetivo clave de esta sección fue generalizar las posiciones revolucionarias del grupo para presentarlas como si fueran comunes a las bases, buscando generar una tensión con el gobierno peronista que "no estaba respondiendo" a los intereses (pretendidamente) revolucionarios de la clase obrera. Esta transferencia se incrementó durante el último período de MPL, cuando el grupo político explicitó sus transformaciones identitarias y rompió abiertamente con la figura de Perón. Finalmente, otro interlocutor fueron las organizaciones hegemónicas de la TRP: Montoneros-JP. Cuando el grupo cuestionó aquellas posiciones que caracterizaban como "movimientistas" y puso sus críticas en "la boca" de "El Negro" y "Francisco", buscando entablar una distancia política entre esas organizaciones y las bases y disputando, como veremos, la representación política de los trabajadores peronistas.

\section{La polémica en torno al tercer gobierno peronista.}

Los primeros números de la revista MPL coinciden con el gobierno de Cámpora y encarnan un momento de expectativas para el grupo político. En efecto, la primera editorial afirmaba que el triunfo electoral peronista abría paso 
a una "experiencia revolucionaria y definitiva" que, además, contaba con Perón como su conductor natural (Revista MPL No1, 14/07/1973). Sin embargo, estas apuestas estuvieron planteadas desde una posición particular; como adelantamos, el grupo MPL expresó un peronismo obrerista que, al amparo de las enseñanzas de Cooke, conllevó definiciones importantes, entre ellas: que la liberación nacional y la revolución social eran instancias indivisibles; el carácter protagónico que asumió la clase obrera y la identificación temprana de contradicciones de clase al interior del peronismo que debían superarse si se buscaba construir el "socialismo nacional".

Estos rasgos fueron ordenadores para la identificación de las políticas públicas (y de los actores políticos) que consideraban "ajenos" al proyecto revolucionario por el que apostaban. Entre ellas, la política económica denominada "Pacto Social" y la designación de Gelbard como ministro de Economía. Es que el "neodesarrollismo" era caracterizado como un modelo vetusto, sustentado sobre la existencia de una burguesía nacional (para ellos inexistente o extremadamente débil) que potenciaría la dependencia (STAVALE, 2018). Otra denuncia temprana giró en torno al rol que las "burocracias sindical y política" jugaban dentro del movimiento y en el gobierno. Estos aspectos se reflejaron puntualmente en la Sección Polémica: el primer intercambio se tituló "carta acerca del Peronismo, la burocracia sindical y el imperialismo" y se encontraba firmada por "Francisco", quien apuntaba:

Compañero: [...] la burocracia sindical aparece realizando una alianza (política) con las fuerzas armadas, en el proyecto desarrollista del neocolonialismo. La burocracia sustituye a la clase trabajadora en la realidad y las fuerzas armadas a la burguesía. Es una política del como sí. Ni detrás de la burocracia están los obreros ni detrás de las fuerzas armadas existe una burguesía nacional (Revista MPL N², 21/06/1973, p. 6, destacado del autor).

La primera carta del intercambio epistolar se ocupaba de definir a los "enemigos" de la liberación nacional y social: las Fuerzas Armadas, que aparecían "alineadas" al imperialismo y la dirigencia gremial que, por otra parte, se presentaba "ajena" a los intereses de la clase obrera. En efecto, "Francisco" afirmaba una "contradicción antagónica y cada vez más desarrollada entre la 
burocracia sindical y el Movimiento peronista” y, vinculando estas denuncias con la política económica, caracterizaba al acuerdo social como un programa "metido de contrabando por Gelbard y compañía [que] ha significado el paso delante de un empresariado pactista que nada tiene que ver con el peronismo" (Revista MPL N², 21/06/1973, p. 6). A pesar de que la idea de un acuerdo social formaba parte de la tradición peronista, la sección subrayaba la ajenidad del programa económico. A la vez, el personaje obrero redefinía los márgenes del peronismo, conectándolo solo a las bases; los dirigentes gremiales quedaban por fuera, a pesar de su pertenencia histórica al movimiento y de sus vínculos con Perón, que además se afianzaron rápidamente.

En efecto, las primeras definiciones públicas del viejo líder se produjeron luego de los hechos conocidos como "la masacre de Ezeiza", desatados el día de su regreso. Aunque el conflicto interno era perceptible desde la asunción de Campora, la masacre simbolizó la puesta en juego en el espacio público y nacional de las luchas intrapartidarias por la totalidad del "verdadero peronismo" (FRANCO, 2011: 23; SIGAL; VERÓN, 2010: 150). Tras el enfrentamiento iniciado por la derecha peronista, Perón apareció vistiendo su uniforme militar y pronunció un discurso que significó un duro revés para los sectores revolucionarios. El líder daba cuentas de su voluntad de pacificación y dejaba atrás el arte de la contradicción discursiva que había caracterizado al exilio (SVAMPA, 2003)

Para el grupo MPL, "Ezeiza" y sus consecuencias, fueron un golpe temprano. A partir de allí, la revista delimitó con mayor claridad a los actores con quienes se enfrentaba dentro del movimiento. En su tercera publicación, se abocaban a analizar los enfrentamientos nombrando como responsables a los dirigentes de la derecha peronista15. En el editorial afirmaban que "el peronismo hoy es como se mostró en Ezeiza, aún con sus lacras que no hemos podido extirpar" (Revista MPL N³, 28/06/1973, p.: 3). Sobre Perón MPL ponía en juego los argumentos de la teoría del cerco -que suponía a un líder engañado por las influencias ejercidas por la derecha peronista. Aunque el grupo sostuvo una relación ambigua con estos argumentos -que se desecharon rápidamente- lo

\footnotetext{
${ }^{5}$ Entre los más destacados: el teniente coronel Jorge Oscinde -subsecretario de deporte en el Ministerio de Bienestar Social, cuyo ministro era José López Rega-, Alberto Brito Lima -jefe del Comando de Organización (CdO) - y a Norma Kennedy.
} 
cierto es que, en este primer momento, echaron mano sobre sus principales axiomas. De esta forma, se señalaba que Perón no era el presidente y que no tenía a su cargo las responsabilidades del gobierno sino otras como la reorganización del Estado y del peronismo (Revista MPL N³, 28/06/1973, p.: 4,5).

Sin embargo, la Sección Polémica escapó al tono general de la revista y denunció explícitamente la dirección que comenzaba a tomar el gobierno y el poder que venían adquiriendo los sectores más conservadores del peronismo. La estrategia discursiva de separar al autor empírico de los autores modelos, permitía que el grupo esgrimiera críticas tempranas en una de sus secciones centrales. En esta oportunidad, "El Negro" retomaba los comentarios de "Francisco":

[...] debo confesarte que estoy preocupado. Mucho burócrata por los ministerios, poco trabajador por las fábricas. Cada vez más desocupados. Yo sé que la hora del pueblo se acerca [...] porque en Ezeiza había 4 palos de pueblo con sus consignas a cuestas. Pero quiero dejarte planteada una pregunta: este gobierno ¿expresa realmente al pueblo? ¿Vamos a construir el socialismo nacional con Rucci, Gelbard y Oscinde? (Revista MPL N 3, 28/06/1973, p. 14).

Simulando el intercambio entre dos trabajadores, comenzaban a sembrar la duda en torno a los objetivos de una experiencia que, días atrás, se presentaba como revolucionaria $\mathrm{y}$, aunque el cuestionamiento no anclaba ni en el movimiento ni en Perón, sí lo hacía respecto de personajes que significaban piezas claves para el programa político del gobierno. Tras Ezeiza, las cartas se centraron en el rol de Gelbard y sus vínculos con "la burocracia”, a pesar de que tanto el Pacto Social como su designación, fueran decisiones explícitas de Perón. En contraposición, MPL hacía hablar a sus trabajadores, quienes afirmaban que "el pueblo que fue a Ezeiza está por el Socialismo Nacional" y que "la patria socialista" surgiría desde la experiencia de las bases (Revista MPL N5, 12/07/1973, p.10).

De manera sutil y casi imperceptible, el liderazgo de Perón comenzó a sopesarse con el de los trabajadores. Aquí resulta interesante analizar las redefiniciones que el grupo MPL realizó sobre el concepto de lealtad: un elemento constitutivo de la conducción política, dentro de la tradición peronista (BALBI, 
2005, p.102-118). Es que MPL afirmaba su lealtad a Perón porque éste encarnaba los intereses del pueblo y del proletariado: esa era la condición que explicaba su liderazgo. En este primer momento, ambas entidades (Perón - clase obrera) tuvieron una convivencia virtuosa, pero cuando la coyuntura se tornó adversa, la dualidad terminó resolviéndose a favor de las bases y esto comenzó a evidenciarse tras la renuncia de Campora.

En efecto, el final de la primavera camporista abrió paso a un momento de transición (y transformación) en la identidad política del grupo MPL que, como todo proceso de crisis, supuso posiciones contradictorias ${ }^{16}$. Si durante los primeros números, la idea de un "Perón cercado" había servido para sortear los golpes de la coyuntura, ese esquema argumental comenzó a desdibujarse. Es que los gestos políticos de Perón se tornaron explícitos y MPL, lejos de buscar justificarlo, comenzó a enfrentarlo a partir de múltiples estrategias, como la de tensionar su vínculo con los trabajadores. En este punto, la Sección Polémica asumió una importancia clave.

En el número 7 publicado el 26 de Julio, "El Negro" tomaba la palabra, definía a las dirigencias gremiales como "el problema concreto" de los trabajadores y, tras reponer un debate con otros compañeros, comentaba:

Cuando ya terminábamos la rueda del mate, Carlitos, que había permanecido callado, largó la pregunta: ¿Decime una cosa, no estaremos equivocados? Porque vos fijate que el viejo lo ha apoyado siempre a Rucci, a pesar de toda nuestra pelea. Carlitos -bastante venido abajo por todo lo que ha pasado en estos días, sobre todo por la renuncia del Tío [...] metía el dedo en la llaga" (Revista MPL Nº 7, 26/07/1973, p. 34).

El "autor empírico" de esta sección comenzaba a cuestionar el vínculo entre Perón y las direcciones burocráticas del movimiento peronista y, en la búsqueda por afianzar la idea de una clase obrera cada vez más consciente (e independiente) de sus verdaderos intereses, ponía en la voz de los "autores

\footnotetext{
${ }^{16}$ A modo de ejemplo, la renuncia de Cámpora no se interpretó como tal, sino como un "golpe de Estado" o "palaciego". Con este tipo de lecturas, el grupo se acercó a la izquierda marxista, que denunciaba un "autogolpe contrarrevolucionario" (Santucho, 1973). Pero, a diferencia de estos sectores, también echaron mano sobre la teoría del cerco al señalar a Perón como una víctima más de un complot perpetrado por la "brujocracia" (síntesis entre la "burocracia sindical" y la derecha comandada por el "brujo" Lopez Rega) y las Fuerzas Armadas (Revista MPL n 6, 19/07/73)
} 
modelos" (dos obreros peronistas) esos cuestionamientos. Es que la identidad peronista estaba en disputa y, con ella, los significados y alcances de la representación de los trabajadores y el pueblo peronista.

En este proceso, Perón no sostuvo una posición equilibrada. Por el contrario, puso en juego sus posiciones explícitamente. A modo ilustrativo, el 30 de julio de 1973, pronunció un discurso en la CGT, que significó un verdadero guiño hacia las dirigencias gremiales: definió los alcances de la revolución peronista y se comprometió a visitar la central una vez por semana "para hablar con los trabajadores" (PERÓN, J.D., 30/07/1973). El viejo caudillo delimitó las fronteras del peronismo y el carácter de su revolución, que lejos de una transformación radical del orden social, se aparejaba más bien a la evolución asociada a cambios estructurales dentro del orden existente. Con la misma línea, pero dos días después, acompañó al presidente provisional Rául Lastiri, en la firma del Acta de Compromiso Nacional junto a los gobernadores. Allí bregó por la conformación de una democracia integrada, llamó a la conformación del Consejo Superior Peronista encargado de institucionalizar el movimiento y volvió a pronunciarse sobre Ezeiza, cuestionando a la "la delincuencia juvenil". Al respecto, dejó en claro que el peronismo no "admitía” la guerrilla y afirmó: "no tenemos inconveniente si ese partido político - se llame Comunista, ERP o Mongo Aurelio [refiriendo irónicamente a Montoneros] quiere actuar dentro de la ley. Pero en lo que sea fuera de la ley, es la Justicia y la Policía la que deberá atender"(PERÓN, 1973)

En su novena edición, MPL publicaba una Sección Polémica particular en la que ambos personajes, "El Negro" y "Francisco" unían sus plumas para responderle a Perón. La carta se publicaba en una revista que explicitaba su posición política: la editorial titulaba "No hay peronismo sin Perón, pero tampoco Perón sin peronismo" y apuntaba: "nuestra clase trabajadora no se inquieta por los discursos que puedan pronunciarse. Sí advierte cuando un proyecto político no le es favorable [...] La relación Perón-Pueblo tiene su correlato lógico y necesario: Pueblo-Perón (Revista MPL N9, 09/08/1973, p. 3).

Es interesante destacar la utilización del adjetivo posesivo "nuestra" para hacer referencia a las bases obreras, pues reafirma aquella disputa a la que 
hacemos referencia. Además, desarticulaban la irrefutabilidad supuesta en la unidad Perón-pueblo, revirtiendo los términos del binomio peronista al advertir que no existe líder sin apoyo popular. Finalmente, fortalecían el carácter clasista de sus planteos, al señalar que los trabajadores eran conscientes de que el gobierno (peronista) no representaba sus intereses de clase. Perón comenzaba a tornarse prescindible, para una revolución que se asentaba sobre la experiencia obrera.

El intercambio epistolar firmado por los autores modelo de la sección, comenzaba de la siguiente manera: "Estimado General: Escuchamos su discurso y quedamos desconcertados [...] Estamos de acuerdo que el Movimiento hay que institucionalizarlo, pero en el gran sentido: transformarlo en una organización revolucionaria [...] de otra forma, significaría integrarlo al Sistema" (Revista MPL N9, 09/08/1973, p.: 10). Más adelante, hacían referencia a las pronunciaciones de Perón sobre la "masacre de Ezeiza" y su crítica a la guerrilla:

La juventud, obreros, estudiantes, provincianos y porteños avanzó sobre Ezeiza para reencontrarse con Usted [...] a los muchachos no nos cabe la menor duda de que la "juventud" cuestionada es la del botón Brito Lima que Usted conoce bien y la de esa supuesta "juventud sindical" [...] No cabe duda de que el Movimiento es de izquierda y como nosotros somos de izquierda, el pueblo es de izquierda (Revista MPL No 9, 09/08/1973, p.: 10, el destacado es nuestro)

El párrafo es contundente y polémico: primero, porque denunciaban implícitamente el vínculo entre Perón y la formación de los grupos de choque de la derecha peronista. A su vez, los personajes retomaban las definiciones de Perón, para darle vuelta: el líder había definido como "de izquierda" al Movimiento, pero había expulsado a los sectores revolucionarios. Aquí "El Negro" y "Francisco" retrucaban: "la izquierda somos nosotros" (los trabajadores) y junto con ellos, el pueblo en general y la militancia revolucionaria (cuestionada por Perón) en particular. Lo que quedaba por ver era si el viejo líder seguía perteneciendo a ese colectivo, o no. A partir de la estrategia discursiva propia a esta sección, MPL presentaba a dos trabajadores que re-definían el significado del peronismo y disputaban el movimiento con el propio Perón. 
Sin embargo, a pesar de estas posiciones, la revista no dejó de apoyar su candidatura. Esta posición -propia del momento de crisis- tiene varias explicaciones posibles: el grupo protagonizaba un juego de espejos y presiones que, bajo una misma identidad política, no renunciaba al peronismo (ROT, 2016, p.110). Aunque comenzaban a ensanchar sus márgenes, esa identificación los Llevaba a asumir una posición ambigua respecto del líder del movimiento. A su vez, existía un lazo afectivo que no debe soslayarse: la pertenencia al peronismo y la identificación con el sentir de las bases. Finalmente, pudo haber significado un cálculo político: el retorno de Perón era una reivindicación popular sostenida por los trabajadores desde su derrocamiento.

De cara a las elecciones presidenciales, MPL enfatizó la idea de que Perón podía corregir la dirección del proceso, pero hizo convivir esta idea con otras dos: la primera, apuntaba que los trabajadores rectificarían "la confianza en el líder" pues "saben por su experiencia histórica, que el único Perón que existe es aquel que hará lo que el pueblo quiere, o dejaría de serlo (Revista MPL N¹5, 20/09/1973, p. 3). Con esta frase, evidenciaban su acercamiento a las posiciones de la organización alternativista PB que, desde épocas tempranas, venía afirmando que el pueblo no abogaba por un hombre sino por lo que él encarnaba (LUVECCE, 1993, p. 86-87). La segunda postura, programática, afirmaba la necesidad de “construir el ejército popular [a partir de] la incorporación activa de la clase trabajadora" (Revista MPL N9, 09/08/1973, p. 9)17.

Estas posiciones se trasladaron a la Sección Polémica. En el número 16, publicado tras el triunfo electoral de Perón, MPL publicaba una carta dónde "El Negro” reponía una conversación con “Olegario”. Allí, este personaje describía la felicidad de las bases, pero alertaba: “[...] jojo! [festejamos] que Perón vuelve a ser presidente. No que López Rega es ministro [...] El pueblo tiene las cosas bien en claro". La carta terminaba de la siguiente manera:

\footnotetext{
${ }^{17}$ Es interesante hacer notar que estas apuestas fueron idénticas a las que FAR había sostenido durante su proceso de peronización. FAR apoyó la apertura electoral que en 1973 permitió el regreso del peronismo al poder, aduciendo que la tarea de los revolucionarios era construir el Ejército del pueblo que permita, luego, la construcción del socialismo (GONZALEZ CANOSA, 2018). MPL usaba estos argumentos en una coyuntura distinta: el gobierno que llamaba a elecciones no era una dictadura, sino que era peronista y las elecciones, consagrarían el retorno de Perón al poder (STAVALE, 2018, p. 156)
} 
Olegario cabeceó con su gigantesca cabezota. El sueño se había agarrado del viejo peronista. Pero me largó la última: creo, me dijo, que la fiesta termina. Que ahora comienza una etapa nueva de lucha en la que es necesario organizarse, no depender para nada de la burocracia sindical y política, marcar un camino de movilizaciones. Si no, nos iremos todos al carajo y los militares se van a poner el gorro de nuevo". (Revista MPL No 16, 27/09/1973, p.: 9 , el destacado es nuestro)

La estrategia editorial de caracterizar a Olegario como un "viejo peronista" parece estar dirigida a justificar las transformaciones de una identidad que se "izquierdizaba", sin renunciar al peronismo. A la vez, la cita confirma aquel cálculo político sugerido párrafos arriba: el apoyo a la candidatura de Perón encarnaba la consumación de un reclamo popular vigente desde 1955 pero, tras el triunfo, la estrategia revolucionaria (el ejército popular con hegemonía obrera), se ponía en la boca de un trabajador peronista.

"Todos los cumpas se preguntan...": los trabajadores de MPL, de frente, contra Perón.

Efectivamente, la presidencia de Perón abrió paso a una nueva etapa. Pero lejos de "corregir la dirección del proceso", el gobierno se endureció a través de un crecimiento significativo de la legislación represiva y de la violencia paraestatal. Esta coyuntura se potenció tras la muerte de José Ignacio Rucci, secretario general de la CGT y pieza clave del "Pacto Social". El hecho (vinculado a Montoneros) marcó un punto de clivaje en el conflicto interno del peronismo y en su proyección para la política nacional (FRANCO, 2013, p.51). En efecto, días después, Perón firmó un Documento Reservado (DR N¹) que impartía órdenes precisas para "limpiar" al movimiento de la "subversión marxista". Como apunta Franco, el documento esclarecía diferencias ideológicas entre marxismo y peronismo, informaba la posición partidaria frente a una "ideología ajena" y llamaba a utilizar todos los medios que "se consideren eficientes" para concretar la "depuración". A su vez, anunciaba la "eliminación” del enemigo infiltrado aludiendo a aquellos grupos que se identificaban "en el marxismo, máxime cuando se presentan como si fueran peronistas" (Documento Reservado N¹, 
02/10/1973). La acusación le cabía a un grupo como el de MPL que, como venimos viendo, ponía en juego estos elementos.

Para el grupo MPL, la posición asumida por el gobierno significó el último zarpazo sobre la herida política que se había abierto con la "masacre de Ezeiza". A partir de este momento, la distancia respecto del movimiento peronista y el rol de Perón se tornó evidente. En efecto, la revista denunció "la ofensiva de la derecha" y el accionar de "verdaderas bandas armadas desde la estructura gubernamental" (Revista MPL N017, 04/10/1973, p. 3) y comenzó a revelar la urdimbre de diálogos y tradiciones que entretejían a la identidad política del grupo: "Liberación o dependencia. No hay terceros caminos [y] Liberación Nacional y Social son indivisibles: la revolución peronista, o surge de las bases [...] o se desdibujará en la más grande de las frustraciones" (Revista MPL N 17, 04/10/1973, p. 4). El agrupamiento negaba explícitamente, uno de los elementos clave de la tradición peronista: "la tercera posición" y ello significaba una posición política clara frente a Perón que seguía proponiendo un camino alternativo a los sistemas imperantes.

El número 18 se posicionó en torno a la publicación del DR1 y trasladó el tema al intercambio epistolar. En la Sección Polémica, se leía: "Francisco: te escribo más preocupado que nunca. Y no sólo yo, todos los cumpas [...] ¿Qué está pasando? Violencia por todos lados, persecución ideológica, documentos (auténticos o falsos, ni se sabe) de depuración, etc." (Revista MPL N¹8, 11/10/1973, p. 7). El número circuló un día antes de la asunción presidencial de Perón y denunciaba que el movimiento había sido "copado por el enemigo" y que servía de herramienta política para el proyecto del "peronismo de arriba" que encaraba una "campaña terrorista" cuyas definiciones emanaban de la publicación del documento (Revista MPL No18, 11/10/1973, p.: 4).

En efecto, semanas después de asumir la presidencia, Perón pronunció un discurso frente al auditorio de la CGT en el que reforzó sus acusaciones a la “infiltración marxista" con metáforas médicas, que llamaban a "desinfectar" el movimiento para evitar que la "enfermedad" avanzara sobre el conjunto (PERÓN, 1973). Este discurso cobra relevancia a la luz del DR No1 y el accionar de la Triple A, organización para-estatal que había comenzado a operar en ese mes y puede 
definirse como uno de esos "anticuerpos institucionales". Con la misma línea, el presidente había "visitado" la Escuela Mecánica de la Armada, evidenciando un claro gesto político hacia las fuerzas. En su publicación número 23, MPL respondió estas definiciones con los tacones de punta: la portada figuraba un comunicado del ejército, parodiando sobre la persecución de un militante: "el Negro Pueblo: alias el infiltrado", cuyas "señas particulares" eran: "pretender comer todos los días", no reconocer aliados en "patrones, burócratas y milicos" o pensar que "Evita es irremplazable" (Revista MPL n²3, 15/11/1973, tapa). Además, la editorial titulaba "Hablemos claro" y entre muchas cosas, afirmaba:

No cabe ninguna duda que el General Perón ha traído al país, desde su largo exilio, un preconcebido plan político. Un esquema de gobierno que por sus particularidades conciliacionistas, de "buena letra con el enemigo", de "desensillar hasta que aclare", etc. se aviene exactamente para ser ejecutado por la burocracia traidora [...]el pueblo no conoce con precisión qué es lo que se propone Perón [...]pero siguiendo sus enseñanzas, sabe que "la única verdad es la realidad" y no puede ser más sombría (Revista MPL No23, 15/11/1973, p. 3).

La revista rompía el cerco y no precisamente aquel que se suponía rodeando a Perón sino la teoría que afirmaba una conspiración en torno a un líder débil y enfermo, que actuaba contra su voluntad. En efecto, "el plan racional" (antes vinculado a la burocracia sindical y política) ahora aparecía ideado por Perón. Con este tipo de posiciones, MPL se acercó a la caracterización que, sobre el viejo líder, venían realizando sectores de la izquierda marxista: cómo la "última carta de la burguesía” para salvar al sistema. ${ }^{18} \mathrm{~A}$ la vez, MPL explicitaba el giro clasista que venía expresándose desde el período previo: "no se trata de apresuramientos o impaciencias. Lo que se cuestiona es el camino elegido: la búsqueda de un capitalismo bueno. No es una cuestión de tiempos" (Revista MPL $N^{\circ} 23,15 / 11 / 1973$, p. 3-4).

\footnotetext{
${ }^{18}$ La organización guevarista Partido Revolucionario de Los Trabajadores - Ejército Revolucionario del Pueblo (PRT-ERP) venía realizando este tipo de lecturas desde épocas tempranas (Stavale S., 2019). Por otro lado, la revista Pasado y Presente en su segunda época (que aglutinó a ex militantes del Partido Comunista y expresó a un marxismo intelectual que venía tejiendo puentes hacia lo nacional y popular desde la década del sesenta) apuntaba la masacre de Ezeiza y la caída de Campora, habían desnudado la voluntad de Perón: "desmovilizar al pueblo y neutralizar a la dirección revolucionaria” (Revista Pasado y Presente N²/3, 07-12 de 1973).
} 
Estas posiciones se trasladaron progresivamente a la Sección Polémica; aunque, hasta el momento, "El Negro", "Francisco" y el resto de los personajes venían expresándose intransigentes frente a las políticas del gobierno y la actuación de las "burocracias" sindical y política, representar la ruptura entre obreros peronistas y Perón, era una tarea diferente. En el número 23, quien tomaba la pluma era "Francisco" y su carta hacía referencia a la visita de Perón a la Marina:

Negro: tu visita del domingo con Olegario y los demás cumpas me dejó pensando [...] todos estaban con los pelos parados por la visita del Viejo a la Marina [...]el viejo, cuenta con el Pueblo y está tratando de unificar a todo el país [metiendo] en la bolsa a los enemigos tradicionales [...]pero la verdad es que no camina. Porque entre ellos y nosotros no hay acuerdo posible y ahora no se trata de repartir la torta, sino de sacársela a los que se la han llevado [...]estoy seguro de que la voluntad del pueblo va a llegar hasta Perón, a pesar de los burócratas que lo cercan[...]porque el viejo, que sabe de historia argentina, sabe también que cuando un caudillo se equivoca de proyecto, para seguir siendo caudillo, tiene que asumir el proyecto que el pueblo quiere.(Revista MPL N²3, 15/11/1973, p. 9)

Es interesante hacer notar la diferencia entre los autores empírico y modelo: si en la editorial del número y en el resto de las notas políticas, el grupo político dejaba atrás los argumentos de la teoría del cero, la Sección Polémica asumía un tono moderado y uno de sus personajes obreros tornaba explícitos los lazos afectivos que entretejían la identidad política de los trabajadores respecto de su líder histórico. "Francisco" apelaba al apodo "el Viejo" y seguía sosteniendo los argumentos del cero. Pero, a la vez, la carta le otorgaba agencia: "sabe de historia argentina" (es decir, sabe qué hace y cuáles son las consecuencias de sus decisiones políticas). Además, la voz de Francisco daba cuentas de la voluntad política de la clase obrera y esa conciencia tomaba forma de advertencia: Perón conoce el proyecto político al que (supuestamente) adhieren las bases peronistas y sabe qué debe hacer para seguir siendo el líder de los trabajadores. Podríamos suponer que una de las estrategias del grupo MPL era responsabilizar al viejo líder de una posible ruptura política con quienes eran considerados "la columna vertebral del peronismo".

Sin embargo, lejos de recoger el guante sobre este tipo de advertencias, Perón sostuvo el programa económico, defendió la cooperación entre la central 
obrera y la empresaria y apoyó a las direcciones gremiales tradicionales, con el objetivo de desactivar el conflicto social y reforzar la autoridad de la CGT (TORRE, 2004). En esta dirección, deben interpretarse las llamadas “leyes gremiales"como la de Prescindibilidad Laboral y la modificación a la ley de Asociaciones Profesionales- que MPL analizó como dispositivos de disciplinamiento para la clase obrera. Es, especialmente, en respuesta a esta coyuntura que los trabajadores de la Sección Polémica potenciaron sus críticas: en la carta número 24, "El Negro" hablaba de "robo social" y retrucaba: "por supuesto que, para Oterito y compañía, estos son los argumentos de un infiltrado. Pero resulta que hay 15 palos de infiltrado de hambre y bronca" (Revista MPL n² 24, 22/11/1973, p. 10).

La crítica al programa económico se articulaba con una maniobra amplia, que lo vinculaba a la política represiva. Ésta, que como hemos dicho, crecía desde la muerte de Rucci, tuvo un salto cualitativo en enero de 1974, con la aprobación de un nuevo Código Penal que preveía un endurecimiento sustantivo de las penas (incluso más allá de lo hecho por la dictadura militar) creando políticas tendientes a garantizar la "seguridad nacional" (FRANCO, 2013, p.73)19. La nueva legislación represiva se complementó con decisiones previas y posteriores: entre las primeras, tras la destitución del Comandante en Jefe de las Fuerzas Armadas, el Gral. Carcagno, se nombró al Gral. Anaya, figura relevante de la última dictadura militar (FRANCO, 2013, p. 73). Al respecto, MPL se preguntó con letras mayúsculas: “¿a quienes derrotó el pueblo el 11 de marzo en las urnas y el 23 de mayo en las calles sino justamente a ellos? ¿Qué tienen que hacer en este gobierno?” (Revista MPL N³0,03/01/1974, p. 7). Entre las decisiones posteriores, se pidió la renuncia del gobernador de Buenos Aires, Oscar Bidegain, acusado de complicidad con los sectores revolucionarios (SERVETTO, 2010).

\footnotetext{
El gobierno venía presionando por la aprobación del Código Penal desde fines de 1973 y encontró la excusa perfecta en enero, luego de que el ERP atacara una guarnición del ejército establecida en Azul. Tras estos hechos, Perón habló por cadena nacional, afirmó que era preciso "aniquilar cuanto antes este terrorismo criminal" e instó al recinto legislativo a aprobar el proyecto. Como consecuencia, debemos mencionar la renuncia de los diputados de la JP, que se negaron a votar a favor. El hecho, conocido como "la renuncia del grupo de los 8" habilitó que Rodolfo Ortega Peña asumiera una de esas bancas. Pero el dirigente del grupo MPL rompió con el FREJULI y creó un bloque unipersonal de Base.
} 
En esta compleja coyuntura, el número 32 se tituló "Ley represiva, vuelta al pasado". La tapa presentó la fotografía de un militante aferrado a las rejas de un establecimiento penitenciario (Revista MPL No 32, 24/01/1974). A la vez, el grupo denunció "la distinta vara”, con la que se juzgaban dos violencias diferentes: la del sistema y la revolucionaria. Dentro de la primera, ahora incorporaban la explotación de los trabajadores, el hambre y la desocupación y se preguntaban "¿Por qué son mercenarios y criminales los militantes de izquierda y no las bandas parapoliciales?” (Revista MPL N³2, 24/01/1974, p. 3). La Sección Polémica de este número, endureció su tono sustancialmente: Titulando "Perón y el Movimiento" el grupo político teatralizaba una conversación entre los personajes obreros y apunta:

Francisco: Te juro que estoy preocupado [...]en las fábricas se advierte cada vez más intranquilidad y tengo la impresión de que para marzo, vamos a tener conflictos grandes. Y te digo lo que me preocupa: que está gobernando Perón. Porque si llega a haber represión a los conflictos (ya está Gendarmería en muchas fábricas) no vamos a entender nada de nada (Revista MPL, No 32, 24/01/1974, p.9).

La carta recreaba un potencial enfrentamiento entre la clase obrera y el gobierno de Perón. Más adelante, "El Negro" compartía la respuesta de "Olegario" quien nuevamente, marcaba la línea del debate político:

Mira Negro, voy a tratar de contarte la cosa tal como la veo yo. Perón siempre ha sido el centro de su movimiento [Pero actualmente] la posición movimientista no encuentra respaldo en la realidad. El Movimiento se encuentra definitivamente partido en dos: burocracia vs. clase trabajadora. Esta separación imposible de pegar con poxipol político, lo obliga a tendenciarse [...] ¿Significa esto que Perón se ha equivocado? Fíjate vos que Perón es un hombre [y] como tal puede equivocarse. Pero [también] es un nombre que sintetiza años de historia política argentina [...] por eso, como este pueblo confronta esa experiencia que lleva adentro con lo que está ocurriendo actualmente, surge el desconcierto. Pero vos fijate que es lo que hace el pueblo: por un lado, no abandona su lucha, pero por el otro, no deja de ser peronista, es más, "profundiza" su peronismo. Porque es desde adentro del peronismo que se "superará" al peronismo [...] No te olvides que la única verticalidad debida es a la Patria, luego al Movimiento y por último a los hombres. (Revista MPL, No 32, 24/01/1974, p. 9) 
La verticalidad (es decir, la lealtad) ya no respondía al líder sino al proyecto de liberación que llevaba in situ el peronismo: "por último a los hombres", decían... y Perón había devenido en uno de ellos (y estaba equivocado). Sin embargo, su nombre también sintetizaba una experiencia política que tenía por protagonista al pueblo. En este punto, la conciencia política de las bases (adquirida a través del peronismo) les permitía reivindicar esa identidad y "profundizarla", aún a pesar de Perón. La carta recoge un movimiento político que antes había sido reclamado por Cooke: la superación del peronismo desde dentro. Aun cuando, a estas alturas, el grupo político había roto abiertamente con Perón, no estaban dispuestos a abandonar al peronismo como identidad política, ni a dejar de luchar desde el movimiento popular.

En el número siguiente, el personaje de "Francisco" retomaba el debate sobre la cuestión de la "verticalidad". Allí, recuperaba fragmentos de la historia del peronismo para afirmar que, durante los 18 años de resistencia peronista "no existió consulta alguna ni verticalidad oficiosa, pues el peronismo genera sus propias realidades revolucionarias, de abajo hacia arriba". Más adelante, continuaba: "el papel de Perón ha sido, al menos hasta la fecha, aceptar esas realidades populares, incorporarlas a su estrategia política. Si ahora no estuviese ocurriendo esto, Negro, es que Perón estaría dejando de ser Perón y entonces, mal podríamos hablar de verticalidad (Revista MPL No 33, 31/01/1974, p. 10). La representación de estas afirmaciones en la pluma de los personajes obreros buscaba afianzar la idea de una disputa entre los trabajadores peronistas y el proyecto político de un Perón-presidente que había dejado de representarlos

MPL estaba próxima a ser clausurada y el grupo político era consciente de esta situación. Sus dirigentes venían siendo amenazados de muerte y la redacción de la revista había sufrido atentados importantes. Esta coyuntura y la ruptura explícita respecto de Perón se expresaron en las últimas cartas del intercambio polémico. En el número 35, la denuncia de organizaciones parapoliciales se puso en la voz de los trabajadores y se vinculó directamente al gobierno de Perón:

Y todo esto, que vos y Olegario y los demás cumpas saben tan bien [...] sin necesidad de prueba alguna, que hoy como en la Dictadura o más aún, existen comandos parapoliciales que están 
secuestrando y asesinando compañeros. [Estas] bandas de ultraderecha [...] son parte del Estado y su aparato represivo y deben existir para que el pacto social -la explotación- siga a delante y para que los trabajadores -todos peronistas- dejen de serlo. (Revista MPL No 35, 21/02/1974, p. 10)

Cuando la escalada represiva golpeó al gobierno provincial de Córdoba destituyendo a sus gobernadores (Obregón Cano y López), MPL tituló "Córdoba avasallada" y editorializó "cada día más gorila”, en referencia al gobierno (y a Perón). La dirección del grupo político era particularmente dura y apuntaba: "en Argentina, se está tratando de llevar a cabo un proyecto burgués, tal vez la última gran tentativa" (Revista MPL N³6,07/03/1974, p. 3). El pasaje refleja la forma en que MPL venía dilatando las fronteras de su identidad peronista, en un giro hacia la izquierda. Lo interesante es que, en este proceso, la revista disputaba los sentidos del "verdadero peronismo" ${ }^{20}$ que aparecía conectado solo a los trabajadores y que excluía a Perón (tildado de gorila) de sus fronteras políticas: "Los trabajadores no dejarán de ser peronistas. Ni nosotros junto con ellos. Porque esta historia nos pertenece, no tiene un dueño único, amo y señor, sino a un pueblo que construye esa historia con su sangre" (Revista MPL N 36, 07/03/1974 p.3).

La Sección Polémica era igualmente beligerante: titulada "todos los cumpas se preguntan", se publicó junto a la foto del viejo caudillo y giró en torno de un diálogo entre El Negro y Olegario:

Decime, Ole ¿vos pensás que Perón ignora todo eso, o lo dirige él? Ole se rió de entrada. Todos los cumpas se preguntan lo mismo, Negro [...] me fui unos días al interior. Allá ya es mufa[...]Allá te afirman que Perón dirige esta política, porque cree que al país se lo va a salvar con la unidad con los patrones, los militares, los burócratas" [Más adelante, El Negro retruca]"Bueno, pero hay algo que no entiendo, Olegario. Si el proyecto del gobierno de Perón es un plan de la oligarquía [...] ¿no significa que vamos a enfrentar a Perón? [...] Olegario se rió un rato: ¿y vos no pensás que él está chocando ya con todos nosotros? (Revista MPL No 36, 07/03/1974, p.13, el destacado es nuestro)

\footnotetext{
20 Altamirano distingue entre "peronismo verdadero" y "empírico": el primero, se define como una expectativa real que cuando se atribuye a los trabajadores, no puede extenderse a los dirigentes políticos o sindicales. Estos últimos forman parte del "peronismo empírico", por detentar poder. Lo interesante a destacar es que el autor afirma que incluso Perón no había expresado siempre el peronismo verdadero y que cuando esto sucedió, el evocador fue otro: el pueblo, la clase obrera o Evita (ALTAMIRANO, 2001,p. 131)
} 
En su antepenúltimo número, el grupo político (o "autor empírico" de esta sección) ponía en boca de los personajes obreros (o "autores modelo") la estrategia de responsabilizar a Perón de la (supuesta) ruptura con los trabajadores. A partir de esta estrategia, la revista buscaba sopesar la carga simbólica de una operación ideológica que separaba al peronismo de su jefe ${ }^{21}$.

Cartas polémicas: Los trabajadores de MPL, sobre Montoneros-JP.

El debate con Montoneros y JP es otra de las aristas que muestran la izquierdización del peronismo como un "cauce de radicalización política" distintivo del grupo MPL. Y se dieron en términos conocidos dentro de la TRP, pues reverdecieron las discusiones entre "movimientistas" y "alternativistas", en torno a aquellos tópicos político-ideológicos decisivos como la definición del proceso revolucionario, la caracterización del movimiento y el rol de Perón o la participación de las instancias del movimiento para impulsar la transformación social (GONZÁLEZ CANOSA; STAVALE, 2021).

Como una de las expresiones políticas más importantes del alternativismo, el grupo MPL interpeló a Montoneros y JP y, aunque por momentos, se acercó al análisis realizado por estas organizaciones, las disidencias políticas predominaron transformándose en duras críticas sobre sus lecturas y posicionamientos políticos (STAVALE, 2018, 2018a). En este camino, un recurso editorial fue afirmar que las posturas movimientistas respondían a una asunción del peronismo "desde afuera”, común al "deslumbramiento" de "los recién llegados" (Revista MPL No 7, 26/07/1973). Esta construcción política, hacía énfasis en los itinerarios previos de los miembros del grupo: es decir, la militancia en el movimiento desde los tempranos sesenta, como un mecanismo de legitimidad para subrayar sus conocimientos sobre las pendularidades de Perón y la realidad ideológica del peronismo.

\footnotetext{
${ }^{21}$ Silvia Sigal pone en juego este concepto para caracterizar a la intelectualidad de izquierda en los tempranos sesenta. Según la autora, "reconocida la realidad política del peronismo", los intelectuales marxistas pusieron en juego diversas "operaciones ideológicas", una de las cuales fue "escotomizar el papel de Perón, separando al peronismo de su jefe [SIGAL, 2002, p. 185].
} 
Esta estrategia se trasladó a la Sección Polémica porque el grupo político (o autor empírico) transfirió sus experiencias a los autores modelo. Además, se reforzaron una serie de rasgos de los personajes obreros, con la intención de 1| diferenciarlos de la militancia que asociaban a JP y 2| legitimar el giro clasista de la propia identidad peronista. El primero tenía que ver con una cuestión generacional: los protagonistas de la sección se caracterizaron como "viejos peronistas", mientras que los "recién llegados" (vinculados al movimientismo) con los sectores juveniles. La segunda (pero íntimamente vinculada), fue la distinción de clase al sobreponer el carácter obrero de los autores modelo, por sobre otras experiencias. A modo de ejemplo, la Sección Polémica número 12 publicaba una carta del compañero "Néstor", salteño y peronista, que apuntaba:

[...] El pibe Gustavo, estudiante de la otra cuadra, puede sentirse derrotado, pensar que se equivocó y chau. Para mí, para el Chango Boedo y para vos, la cosa es distinta, no podemos darnos el lujo de sentirnos derrotados [...] Nosotros aprendimos a ser peronistas con el corazón y el estómago, y después con la cabeza." (Revista MPL No 12, 30/08/1973, p. 9)

Finalmente, otro rasgo importante fue la cuestión geográfica: trabajadores del interior vs "los porteños". Los personajes eran obreros de base y muchos escribían desde el resto de las provincias del país. En reiteradas oportunidades, se apeló a ésta última condición para subrayar la legitimidad de las propias posiciones:

Allá ven con simpatía la política de las organizaciones armadas, pero [coinciden] en la propuesta política global de no romper, por lo menos por ahora, con la burocracia sindical ni con el empresariado imperialista. Esto no es un problema de fe ni de esperanza, como pueden creer compañeros de BsAs., al fin y al cabo, porteños ellos. Perón nos abre una gran puerta, pero somos nosotros los que tenemos que pasar por ella, no los burócratas ni los militares del Sistema, ni los empresarios del Pacto Social. (Revista MPL No 13, 06/09/1973, p. 7)

Este fragmento es interesante, pues pone en boca de un trabajador peronista los principales ejes del debate que MPL buscaba darle a MontonerosJPr: el reconocimiento de las contradicciones de clase al interior del movimiento (y el llamado a dar la disputa interna con las dirigencias políticas y gremiales); la denuncia del programa económico (y cuestionamiento de una alianza con la 
"burguesía nacional") y el rechazo a que las fuerzas armadas pudieran ser un potencial aliado en un frente de liberación.

El nudo central en la argumentación de MPL radicó en la denuncia de que Montoneros-JP estaban "conviviendo con el enemigo", a partir de una posición movimientista que buscaba preservar los espacios políticos e institucionales logrados, evitando la "autoexclusión" del movimiento peronista²2 (STAVALE, 2018). Estas críticas pueden analizarse a partir de tres acontecimientos concretos: la participación de Montoneros-JP en el acto de apoyo a la candidatura de Perón organizado por la CGT el 31 de agosto; su alineación al discurso del Gral. Carcagno en la Conferencia de Ejércitos Americanos -CEA- y el accionar conjunto de la JP y el Ejército en el "Operativo Dorrego".

Respecto del acto organizado por la dirigencia gremial en apoyo de la fórmula presidencial Perón-Perón, Montoneros-JP aceptaron la convocatoria y la interpretaron en términos positivos. Desde su órgano oficial, la revista El Descamisado (ED), afirmaron haber "copado el acto" y celebraron el "retorno de Perón" pues "la realidad del regreso está dada por el encuentro físico" (Revista ED No16, 04/09/1973, p. 4). En marcado contrapunto $-y$ alineados al posicionamiento del PB, que no movilizó- MPL afirmó que esa participación había significado un "aval para la burocracia, alineando a JP con su proyecto político general y motivando una sonrisa de triunfo en Lorenzo Miguel y Rucci” (Revista MPL No 12, 30/08/1973, p.3). La Sección Polémica se hizo carne de estas críticas en la voz del "Chango Boedo":

\footnotetext{
${ }^{22}$ Resulta importante apuntar que, a pesar de que Montoneros-JP pudieran asumir posiciones cercanas al movimientismo, caracterizarlas como tales fue, también, una construcción del grupo MPL. La revista discutió fundamentalmente con las posiciones públicas de las organizaciones hegemónicas del peronismo revolucionario que circularon en la prensa oficial y oscilaron entre una crítica solapada al presidente y los argumentos de la teoría del cerco (SLIPAK, 2015). Sin embargo, hacia dentro, Montoneros comenzó a radicalizar sus contradicciones con el viejo líder (OTERO, 2019). En efecto, en octubre de 1973 circuló un documento entre los cuadros dirigentes que se conoció como "el mamotreto" y que reflejó posiciones izquierdistas y una autocrítica sobre la forma en que habían caracterizado al líder y al proceso abierto tras el 25 de mayo. Sin embargo, ese documento no se reflejó en las posiciones públicas de la organización. En efecto, allí mismo terminaban afirmando que "sería estúpido pelearnos con Perón por la ideología... no por eso nos vamos a ir del peronismo, no tiene el más mínimo sentido porque compartimos el proyecto estratégico que formula Perón, aunque nosotros vayamos más allá" (BASCHETTI, 1997: 293).
} 
Es necesario que veamos en serio lo que está pasando, sin pedanterías. Sin confundir religión o filosofía con lucha revolucionaria. Ni fe ciega, ni escepticismo inmovilizante [...]si queremos acabar con el hambre y con los desocupados, tiene que ser una propuesta que tienda al socialismo. No es configurando una nueva burocracia o con una alianza con la vieja que vamos a derrotar al enemigo, por más carteles que enarbolemos. Porque en los últimos días que estuve en BsAs. he visto eso que Ustedes llaman perejiles por todos lados. Y esos, a lo sumo y a las últimas, pueden venir en el montón, pero no dirigir nada. (Revista MPL No 13, 06/09/1973, p. 7).

El grupo transfería sus críticas al personaje obrero, cuestionando la representación política de la organización más importante del peronismo revolucionario. Además, alineaba a los obreros de base con sus apuestas políticas: la polémica salía publicada junto a la sección "bases sindicales" que titulaba "la organización independiente de la clase obrera" y sintetizaba la posición del alternativismo.

Este tipo pasajes evidencia que la identidad peronista estaba en disputa y que ésta no se daba solo con la derecha del movimiento, sino también al interior del espectro revolucionario. Es que las diferencias programáticas entre MPL y Montoneros se tornaron evidentes: si para éstos, el proceso revolucionario seguía articulado en la construcción de un Frente de Liberación Nacional, para el grupo dirigido por Ortega Peña y Duhalde que, como vimos, definía a la liberación nacional y social como instancias indivisibles de un mismo proceso, la clave pasaba por construir un frente revolucionario; volveremos sobre este punto.

Interesa subrayar ahora, que estas diferencias tenían especial injerencia en la forma en que se interpretaba el proyecto político de gobierno. Si, por ejemplo, Montoneros-JP expresaba públicamente estar a favor de una "alianza de clases" pero no con "la forma que estaba asumiendo el pacto social" (Revista ED Nº 31, 18/12/1973), MPL respondía explícitamente, interrogándose con ironía: “¿No será que directamente es otra cosa que lo que El Descamisado analiza? El malabarismo que se hace para explicar este ser que tiene cola de pacto social, cara de pacto social pero que no es un pacto social, llama la atención singularmente" [Destacado del autor]. En efecto, el grupo retrucaba que el pacto social "es, como decíamos, el acuerdo del Gran Capital con la Burocracia. Sin tanta vuelta, confusión y contradicción (Revista MPL N²8, 20/12/1973, p. 16). 
Con la misma línea, la Sección Polémica volvía a relatar una reunión de compañeros y reponía las respuestas de Olegario a "los pibes" que se habían reunido para escucharlo. Nuevamente, se enfatizaban las diferencias generacionales como mecanismo de legitimidad. El "viejo peronista" afirmaba haber leído las declaraciones de la JP y afirmaba: "se trata de volver a la situación anterior a 1955 [...] pero fíjense que, si volvemos, la caída se volverá a repetir". Más adelante, Olegario respondía:

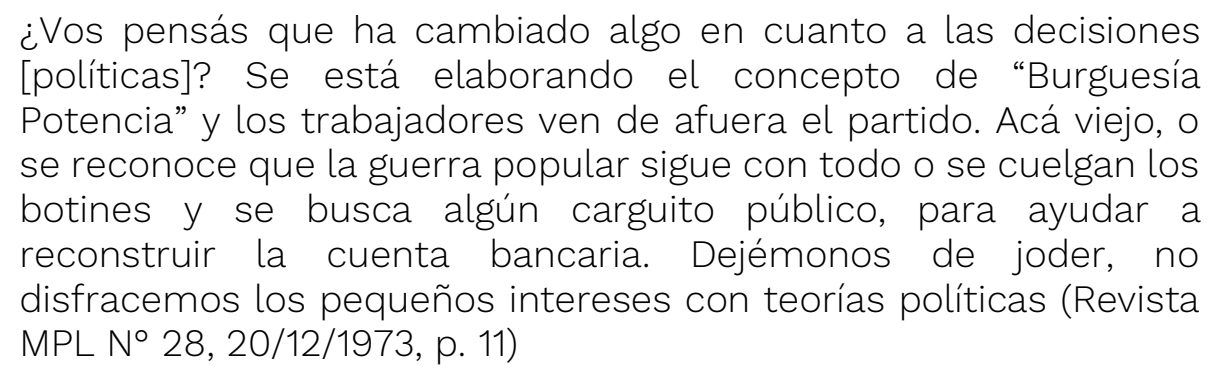

Este tipo de críticas (que cuestionan la estrategia de apelar a las instancias de inserción en el gobierno, a partir de la pertenencia al movimiento) se replicaron ante el posicionamiento de Montoneros-JP respecto de las Fuerzas Armadas, como potencial aliado en un Frente de Liberación. La primera polémica giró en torno al discurso de Carcagno en la CEA. En términos generales, el comandante en jefe de las fuerzas armadas había defendido como principios "básicos e inalienables" la no intervención de Estados Unidos y la autodeterminación de los pueblos, oponiéndose a las doctrinas norteamericanas para América Latina y el mundo.

Entre los sectores revolucionarios, el discurso produjo interpretaciones disímiles: si Montoneros lo apoyó afirmando a través de ED que en las armas, también penetraban las contradicciones sociales (Revista ED N017, 11/09/1973, p. 28), la organización guevarista ERP intentó copar el Comando de Sanidad del Ejército. Con el golpe militar contra Allende en Chile como escenario, MPL se posicionó especialmente esto, afirmando: "La factibilidad de una posición real antiimperialista de los ejércitos latinoamericanos, parece encontrar, como limitación absoluta, la resistencia de esas fuerzas a que el antiimperialismo adopte posiciones concretas de construcción nacional del socialismo" (Revista MPL No 14, 13/09/1973, p.4). Una vez más, MPL se distanciaba de Montoneros y se 
acercaba al análisis de la izquierda marxista, a pesar de que la revista criticó el intento en Sanidad por sus consecuencias represivas.

La posición del grupo se trasladó a la polémica obrera: las cartas de “Francisco” se titulaba: “¿los militares se han vuelto peronistas?” y el personajeobrero afirmaba que, para acercar un posicionamiento certero sobre las fuerzas armadas y su vínculo con la liberación nacional y social, había que revisar la “historia personal de Carcagno, que demuestra que la conversión es sospechosa" (Revista MPL No 15, 20/09/1973, p. 8). Retrucando algunas de las definiciones que había realizado ED, la sección respondía que "sin perjuicio de que existan, y existen, oficiales revolucionarios [...] las FFAA no son un lugar donde se den todas las contradicciones de la sociedad, sino que en ellas se asumen, por el contrario y claramente, los intereses de la burguesía" (Revista MPL No 15, 20/09/1973, p.:8). La carta da cuentas del giro clasista que venía realizando MPL y una pretendida articulación entre la propia identidad y la de las bases.

La línea de MPL se endureció cuando el 5 de octubre la JP puso en marcha el Operativo Dorrego que, en conjunto con el Ejército, buscaba colaborar con la reconstrucción de barrios de la provincia de Buenos Aires afectados por las inundaciones. En el número 19, publicado el 18 de octubre, la revista afirmaba que "el hecho de referencia no aporta sino oscuridad al proceso político, porque el ejército represor [...] no ha cambiado en su esencia por el tono de un discurso" [en referencia a Carcagno]. Endureciendo el análisis, MPL afirmaba que el Ejército no devenía en "ejército del pueblo" por una expresión de deseo de la JP que "en una de esas, un día descubre que, en vez de haber trabajado por la Argentina Socialista, estuvo poniendo sus esfuerzos en la "Argentina Potencia" [expresión utilizada por Gelbard, para señalar los objetivos de crecimiento económico de su programa] (Revista MPL N¹9, 18/10/1973, p. 14). En la Sección Polémica, "El Negro" relataba:

Francisco: el domingo nos reunimos en lo de Olegario [...]el tema político no había surgido hasta que Estela contó que su sobrino estaba participando del Operativo Dorrego. Ahí saltó el cabezon [Olegario]. Pero díganme una cosa, ¿a los pibes que les pasa? ¿No se dan cuenta de cómo los están haciendo ganar a los militares con cosas como esas? Yo no entiendo un carajo, pero la cosa está bastante clara. Tras años de dictadura, con todo el pueblo en contra, los militares necesitan que el pueblo no los desprecie [...]ahí está la calve, muchachos, no han cambiado en lo más 
mínimo. (Revista MPL No 20, 25/10/1973, p. 10, el destacado es nuestro)

La carta subrayaba otra vez el carácter “juvenil” de la militancia montonera, contraponiéndola a la experiencia de los (sus) trabajadores. En efecto, continuaban afirmando: "Se ponen la piel de cordero [...] porque saben del prestigio de la JP en el pueblo. Necesitan disfrazarse de pro-peronistas. [...] por eso, creo que el error táctico de los muchachos es nefasto" (Revista MPL N²0, 25/10/1973, p.:10).

Al calor de la confrontación con los sectores hegemónicos de la TRP, MPL fue delineando sus apuestas políticas: la exacerbación del "peronismo obrero" se vinculó con la propuesta de construir una organización revolucionaria para y de los trabajadores: la "alternativa independiente". En este camino, se tejieron vínculos con los sectores del peronismo revolucionario que venían sosteniendo, en mayor o menor medida, la necesidad de construir esa alternativa: fundamentalmente, con el PB, pero también con la McJSN o con las expresiones alternativistas del sindicalismo combativo. En reiteradas oportunidades, MPL se alineó a sus análisis y decisiones políticas y, al mismo tiempo, dispuso algunas de sus secciones centrales para que las diferentes organizaciones publiquen cartillas orgánicas o materiales de discusión política. Esta alineación se torna evidente en los trabajadores protagonistas de la Sección Polémica, quienes se definían "obreros y de base" y asumían la propuesta alternativista, tejiendo un puente directo con el PB.

Pero a la vez, acorde al proceso de izquierdización de la identidad peronista, MPL elaboró una propuesta concreta: la formación de un frente revolucionario entre las organizaciones peronistas y marxistas que denominaron "el Frente de Trelew". Con la nominación, homenajeaban al plan de fuga de 1972, que terminó en masacre y que había comprometido en un accionar conjunto a las direcciones políticas de las organizaciones FAR, PRT-ERP y Montoneros ${ }^{23}$.

\footnotetext{
${ }^{23}$ Los miembros del grupo MPL habían militado en "la Gremial de Abogados", ejerciendo la defensa de presos políticos durante la dictadura militar. La apuesta por la confluencia encontraba sus raíces en estos itinerarios: el grupo se había vinculado con todas las organizaciones revolucionarias, asumiendo la defensa de cualquier preso político, sean marxistas o peronistas. Además, casi todos ellos habían participado de la defensa de los presos de Trelew, antes de la masacre. (STAVALE, 2018).
} 
De esta forma, la revista hizo convivir las críticas a Montoneros con la convocatoria siempre abierta y vigente a un frente revolucionario. La propuesta constituía un mensaje político que se dirigía a la militancia que quería la confluencia y, probablemente, buscó presionar a la dirigencia de Montoneros-JP, que rechazaba públicamente confluir con la izquierda marxista ${ }^{24}$. Estas "presiones" se trasladaron a la Sección Polémica pues allí, la revista representaba la (pretendida) posición de los obreros peronistas. En el número 30, una carta firmada por "El Negro", apuntaba:

He leído hace poco, que hay que reconstruir el Frente de Trelew, es decir, la unidad del peronismo revolucionario con la izquierda que quiera plegarse en una confluencia honesta y revolucionaria, como sostenía el gordo Cooke. Y darse un programa de lucha para la clase obrera peronista. Si esto se emprende en serio podemos ganarla. Sino todo se irá a la mierda (Revista MPL Nº 30, 03/01/1974, p.9)

Las apuestas de la revista se tornaban urgentes, en una coyuntura cada vez más agobiante. Sin embargo, convivían con las críticas que llegaban a alinear a Montoneros-JP con un peronismo asumido "desde afuera", lo que significaba cuanto menos- un obstáculo para la apuesta de unificar al peronismo revolucionario en torno a la perspectiva propia.

\section{Reflexiones Finales}

A lo largo de este artículo, buscamos analizar específicamente una de las secciones más relevantes de la revista MPL: la Sección Polémica. Como hemos apuntado, esta supuso un particular "contrato de lectura" que se basó en el desdoblamiento entre el autor empírico y los autores modelo. La estrategia editorial permitió que el grupo político "dijera lo indecible" desde épocas tempranas, con la particularidad de que quienes parecían pronunciarse fueron

\footnotetext{
${ }^{24}$ Siguiendo a González Canosa, observamos que esta resistencia no era nueva en Montoneros: ya en 1972, fuera del penal de Rawson, la cúpula montonera no se comprometió con el plan de fuga e incluso, cuestionó a FAR por su accionar conjunto con ERP durante ese año (2012, p. 249250). En este punto, la apuesta por re-editar el "Frente Trelew" en una coyuntura completamente distinta fue una construcción política (y una apuesta) de MPL en pos de la unidad: un modelo a seguir, mitificado por la épica de la fuga y la tragedia de la masacre (STAVALE, 2018).
} 
los trabajadores peronistas. Una característica interesante que debemos destacar es que las notas de MPL no se firmaban y, en consecuencia, no podía saberse a ciencia cierta si las “cartas en polémica” eran verdaderas o no. De esta forma, el grupo político generó una ilusión de realidad que apuntó a reforzar un cuestionamiento que, supuestamente, provenía de las bases.

Por todo esto, el análisis de la Sección Polémica es una suerte de prisma que evidencia un proceso más general: el de la transformación identitaria del grupo MPL que, sin abandonar el peronismo, se radicalizó hacia la izquierda. Y también, permite dar cuenta de las apuestas políticas del grupo: tanto en la asunción del alternativismo, como en la disputa sobre los sentidos del "verdadero peronismo" con los sectores internos del movimiento, el propio Perón e, incluso, las organizaciones hegemónicas de la TRP.

En este movimiento, destacamos la centralidad de una sección que puso en juego la construcción política que MPL realizó sobre el rol de los trabajadores, trasladando sus posiciones político-ideológicas a la realidad de los sectores populares como si ellos fueran sus protagonistas. Por este motivo, constituyó un espacio clave desde dónde apostaron por la autonomía de la clase obrera y argumentaron un potencial enfrentamiento entre los trabajadores y Perón. Es decir, es una sección que muestra la forma en que el grupo político redefinió los márgenes del peronismo, expandiendo su enfoque a partir de un giro clasista que reclamó "el peronismo de los trabajadores", dislocándolo de Perón y de su experiencia de gobierno.

Vimos, también, que esas transformaciones repercutieron en el debate que la revista buscó dar al interior del peronismo revolucionario: la opción por un peronismo obrerista y marxista, allanó el vínculo entre MPL y el alternativismo, al tiempo que parió como propuesta política la construcción de un frente revolucionario que reuniera a las organizaciones marxistas y peronistas para la construcción del socialismo. En este camino, la revista fue duramente crítica respecto de las posiciones de Montoneros-JP, caracterizadas como "movimientistas".

Finalmente, pero en íntima vinculación, debemos decir que tanto la Sección Polémica como la construcción del peronismo "de abajo" eran -al fin y 
al cabo- eso: una construcción política:¿Cuánto de esa clase obrera estuvo, finalmente, dispuesta a romper con Perón?¿Cuál fue la representatividad real de este tipo de posicionamientos, al interior del movimiento obrero? ¿Y al interior de la TRP? En este punto, podríamos suponer que los/as trabajadores/as peronistas constituyeron otro “lector modelo" para el grupo político, que buscó interpelarlos poniendo en juego suspercepciones sobre el rol que debían tener en el proceso revolucionario buscado.

\section{Referencias}

ALTAMIRANO, C. Peronismo y cultura de izquierda. Buenos Aires: Siglo XXI, 2001

CHAMA, M. La defensa de los presos políticos a comienzos de los $70^{\prime}$ : ejercicio profesional, derecho y política. Cuadernos de Antropología Social, v. 32, p. 195217, 2010.

BALVÉ, B. El 69: huelga política de masas: Rosariazo/ Cordobazo/ Rosariazo. Buenos Aires: Contrapunto, 1989.

BARTH, F. Los grupos étnicos y sus fronteras: la organización social de las diferencias culturales. México: Fondo de Cultura Económica, 1976

BOZZA, A. La resignificación revolucionaria del peronismo y sus protagonistas durante la etapa de proscripción. In: TORTTI, Cristina; CHAMA, Mauricio; CELENTANO, Adrián(eds.).La "nueva izquierda argentina": socialismo, peronismo y revolución. Rosario: Prohistoria, 2015.p. 59-82.

BRENNAN, J. El Cordobazo: las guerras obreras en Córdoba 1955-1976. Buenos Aires: Editorial Sudamericana, 1996.

CAMPOS, E. Cristianismo y revolución: el origen de Montoneros: violencia política y religión en los 060. Buenos Aires: Edhasa, 2016

CELECIA F.;WAISBERG, P. La ley y las armas: biografía de Rodolfo Ortega Peña. Buenos Aires: Editorial Aguilar, 2007.

CULLEN, R. Clase obrera, lucha armada, peronismos: vol I: génesis, desarrollo y crisis del peronismo original. La Plata: Editorial de la Campana, 2008

DOCUMENTO RESERVADO NúMERO 1, Consejo Superior del Movimiento Peronista. In: BASCHETTI, R. Documentos: 1973-1976. La Plata: Editorial Campana de Palo, 2008.p. 66-69. 
DUHALDE, E.;PEREZ, E.De Taco Ralo a la alternativa independiente: historia documental de las Fuerzas Armadas Peronistas y el Peronismo de Base.La Plata: de la Campana, 2003.

ECO, Umberto. El lector modelo. In: ECO, Umberto. Lector in fábula, Barcelona: Lumen, 1987.

FRANCO, M. Un enemigo para la Nación: orden interno, violencia y "subversión", 1973-1976. Buenos Aires: Fondo de Cultura Económica, 2012.

GILLESPIE, R.Soldados de Perón: historia crítica sobre los Montoneros. Buenos Aires: Sudamericana, 2008.

GIMENEZ, G. Estudios sobre la cultura y las identidades sociales. México: CONACULTA e Instituto Tecnológico y de Estudios Superiores de Occidente, 2007

GONZÁLEZ CANOSA, M. Las organizaciones armadas peronistas (OAP): un análisis comparativo de los (re) posicionamientos de las FAR. In: TORTTI, Cristina; CHAMA, Mauricio; CELENTANO, Adrián (eds.).La "nueva izquierda argentina”: socialismo, peronismo y revolución. Rosario: Prohistoria, 2015.

GONZÁLEZ CANOSA, M. Los futuros del pasado: marxismo, peronismo y revolución: una historia de las FAR. Buenos Aires: Prometeo, 2021.

GONZÁLEZ CANOSA, M.; STAVALE, M. Peronismo, izquierda y lucha armada. Balance bibliográfico y perspectivas analíticas sobre las organizaciones armadas peronistas en clave comparada. In: Dossier: Más allá (y más acá) de Montoneros: actores, experiencias y sentidos del peronismo revolucionario en el pasado reciente argentino, Revista Páginas, Buenos Aires, Vol. 13, n. 31 , https://doi.org/10.35305/rp.v13i31.462, 2021.

GURRUCHARRI, E.; PÉREZ, E.; FONTANA, E., ALAFARO S. La patria socialista: una historia de la corriente del peronismo revolucionario MRP-JRP-FRP-MR17-FR17, Buenos Aires: Ediciones en Lucha, 2020.

LANUSSE, L. Montoneros: el mito de sus doce fundadores. Buenos Aires: Editorial Vergara, 2005.

LAUFER, R. Intervención de las izquierdas y politización obrera en SITRACSITRAM, la experiencia paradigmática del sindicalismo clasista de los '70". Izquierdas, Santiago de Chile, n. 49, p.743-766, abr. 2020.

LENCI, M. L. Cámpora al gobierno, Perón al poder. La tendencia revolucionaria del peronismo ante las elecciones del 11 de Marzo de 1973. In: PUCCIARELLI, 
Alfredo (ed.). La primacía de la política: Lanusse, Perón y la Nueva Izquierda en tiempos del GAN, Buenos Aires: Eudeba, 1999. p. 167-201.

LUVECCE, C. Las fuerzas armadas peronistas y el peronismo de base. Buenos Aires: CEAL, 1993.

OTERO, R. Montoneros y la memoria del peronismo. Buenos Aires: Prometeo, 2017.

PASTORIZA, E. Escribir historia política, escribir historia: entrevista con Juan Carlos Torre. PolHis, Buenos Aires, Año 4, n. 8, p. 241-245,2011.

PERÓN, J. D. Discurso pronunciado en la CGT. Buenos Aires, 30 jul. 1973a. Disponible en: www.ruinasdigitales.com. Acceso en: 01/06/2020.

PERÓN, J. D.Discurso a los gobernadores. Buenos Aires, 02 ago. 1973b. Disponible en: www.ruinasdigitales.com Acceso en: 01/06/2020.

PERÓN, J. D.La doctrina, fundamento de la organización. Buenos Aires, 08 nov. 1973c. Disponible en: www.ruinasdigitales.com Acceso en: 01/06/2020.

PORTANTIERO, J.C. Economía y política en la crisis Argentina, 1958-1973. En Revista Mexicana de Sociología, DF Mexico, Vol. 38, p. 531-565, 1977.

POZZI, P.; SCHNEIDER, A. Los setentistas: izquierda y clase obrera: 1969-1976. Buenos Aires: Eudeba, 2000.

RAIMUNDO, M. Izquierda peronista, clase obrera y violencia armada: Una experiencia alternativa. Sociohistórica, La Plata, n. 15/16, p. 99-128 2005.

Revista El Descamsiado, n. 16, 17 y 31, 1973. Disponibles en:_El Topo Blindado. Centro de Documentación de las organizaciones político-militares argentinas, www.eltopoblindado.com Acceso en: 01/06/2020.

Revista Militancia Peronista para la Liberación, n. 1, 2, 3, 5, 6, 7, 9, 12, 13, 14, 15,16, 17, 18, 19, 20, 23, 24, 28, 30, 32, 33, 35, 36, 1973 - 1974. Disponibles en: El Topo Blindado. Centro de Documentación de las organizaciones político-militares argentinas, www.eltopoblindado.com. Acceso en: 01/06/2020.

Revista Pasado y Presente, Año IV, No 2-3, Julio-Diciembre de 1973. In: Biblioteca Nacional (Ed.) Revista Pasado y Presente. Edición Facscimilar, Buenos Aires, 2014. 
ROT, G. Itinerarios revolucionarios. Eduardo L. Duhalde y Haroldo Loguiurato. De la Resistencia Peronista al Partido Revolucionario de los Obreros Argentinos. La Plata: Editorial de la Campana, 2016.

SALCEDO, J. Los montoneros del barrio, Buenos Aires: EDUNTREF, 2011.

SANTUCHO, M.R. Las definiciones del peronismo, las tareas de los revolucionarios. En: El Combatiente N 83, 84 y 85, 1973.

SEMINARA, L. Bajo la sombra del ombú. Montoneros Sabino Navarro, historia de una disidencia. Buenos Aires: Imago Mundi, 2015.

SERVETTO,A. 73/76: El gobierno peronista contra las "provincias montoneras". Buenos Aires: Siglo XXI, 2010.

SIGAL, S. Intelectuales y poder en Argentina. La década del sesenta, Buenos Aires: Siglo XXI, 2002.

SIGAL, S.;Verón, E. Perón o muerte: fundamentos discursivos del fenómeno peronista. Buenos Aires: Eudeba, 2010.

SLIPAK, D.Las revistas montoneras. Cómo la organización construyó su identidad política a través de sus publicaciones, Buenos Aires: Siglo XXI, 2015.

STAVALE, M. Las Fuerzas Armadas Peronistas y su experiencia alternativa, 19641979. Tesina de Licenciatura, FaHCE- UNLP, 2012

STAVALE, M. Las revistas Militancia Peronista para la Liberación y De Frente, con las Bases Peronistas: una propuesta" alternativa" para la identidad política del peronismo revolucionario, 1973-1974, Tesis Doctoral, FaHCE - UNLP, 2018.

STAVALE, S. Perros en las fábricas: La política sindical del PRT-ERP, sus prácticas y la experiencia de sus militantes en fábricas del Gran Buenos Aires, 1973-1976, Tesis Doctoral, FaHCE-UNLP, 2019.

SVAMPA, M. El populismo imposible y sus actores, 1973-1976. In: JAMES, Daniel (dir.).Nueva historia Argentina. Buenos Aires: Sudamericana, 2003.p. 381-438.

TOCHO, F. Lógicas políticas en tensión: La Tendencia Revolucionaria del Peronismo y su participación en el gobierno constitucional de la provincia de Buenos Aires (1973-1974), Tesis Doctoral, FaHCE-UNLP, 2020.

TORRE, J.C. El gigante invertebrado. Los sindicatos en el gobierno, Argentina 1973-1976. Buenos Aires: Siglo XXI, 2004. 
TORTTI, M.C. El viejo partido socialista y los orígenes de la "nueva" izquierda.

Buenos Aires: Editorial Prometeo, 2009.

TORTTI, M.C.; CHAMA, M.; CELENTANO, A. (eds.). La "nueva izquierda Argentina": socialismo, peronismo y revolución. Rosario: Prohistoria, 2015.

VERÓN, E. Cuando leer es hacer: la enunciación en el discurso de la prensa gráfica. In: FRAGMENTOS DE UN TEJIDO. Barcelona: Gedisa, 2004. p. 171 -182. 